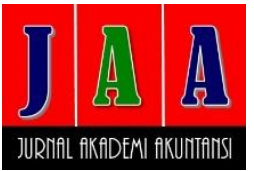

\title{
ANALISIS KINERJA REKSADANA SYARIAH DI PASAR MODAL INDONESIA MENGGUNAKAN METODE SHARPE
}

\author{
Raudhah Trisna Wardhani*, Ahmad Juanda, Dhaniel Syam \\ Program Studi Akuntansi Fakultas Ekonomi dan Bisnis \\ Universitas Muhammadiyah Malang \\ Jl. Raya Tlogomas No. 246 Malang \\ *Corresponding author: Raudhahtw@gmail.com
}

\begin{abstract}
The purpose of this study is to analyze the performance of Islamic mutual funds that include stocks, fixed income, mixes, and money markets using Sharpe method. The type of research conducted is quantitative descriptive research. Data collection method in this research is documentation technique with secondary data that is through official website bareksa.com. In performance measurement, in this research, the researcher only use one method only that is a method of shape. The performance of mutual funds using this shaping method can be analyzed using three indicators; the rate of return of mutual fund, the risk of a mutual fund with standard deviation, a method of shape. Based on the calculation of Sharpe can be concluded that the highest performance among Islamic mutual funds that include stocks, fixed income, mix and money market in 2015, 2016, 2017 is sharia mutual fund shares. Sharia mutual fund shares can be said to be the highest because in the three performance indicators mentioned above mutual funds sharia shares obtain the highest results when compared with other types of mutual funds sharia.
\end{abstract}

Keywords: Performance, syariah mutual fund, Sharpe method.

Diterima 2 Sept 2018

Direviu 16 Sept 2018

Direvisi 26 Okt 2018

Diterima 28 Okt 2018

Artikel ini tersedia di website :

http://ejournal.umm. ac.id/index.php/jaa

\section{PENDAHULUAN}

Pasar modal memberikan berbagai manfaat bagi perekonomian Indonesia, pertama pasar modal menyediakan pertemuan antara debitur dan kreditur. Dana yang diperoleh debitur dapat digunakan untuk menambahkan modal bagi usahanya, ekspansi dan pengembangan usahanya. Penambahan dana yang disediakan oleh pasar modal akan meningkatkan kinerja perusahaan. Kinerja perusahaan yang meningkat akan memberikan kontribusi pajak yang tinggi bagi negara. Pajak yang tinggi dapat digunakan untuk membangun negara sehingga masyarakat luas dapat menikmati hasil pemerataan pendapatan.

Kedua, peran pasar modal yaitu menyediakan sarana investasi untuk para investor. Sarana yang ditawarkan investasi meliputi saham, obligasi, dan reksadana. Investor yang membeli surat berharga akan mendapatkan tingkat pengembalian dan deviden. Deviden yang diperoleh akan dipotong untuk pajak negara. Pajak yang dipotong akan meningkatkan pendapatan negara.

Salah satu surat berharga yang ditawarkan di pasar modal yaitu reksadana syariah. Hasbi (2010), menjelaskan berbagai macam jenis reksadana syariah muncul, diantaranya yaitu reksadana syariah saham, reksadana pendapatan tetap, reksadana syariah campuran, dan reksadana syariah terproteksi. Reksadana syariah sangat diminati oleh para investor. Investor sangat berminat dengan investasi ini dikarenakan sesuai prinsip Al-Quran dan Hadis. Reksadana Syariah harus terhindar dari riba, masyir, gharar. Riba dapat diartikan sebagai pengambilan tambahan keuntungan. Prinsip masyir dapat 
diartikan sebagai spekulasi, sedangkan gharar di definisikan sebagai ketidakjelasan.

Menurut Sutedi (2011:32), apabila kita melihat dalam Al-Quran dan Hadis sebagai sumber utama ajaran Islam maka kita dapat melihat beberapa ketentuan mengenai hal tersebut:

“...Allah telah menghalalkan jual beli dan mengharamkan riba...” (QS Albaqarah (2):275).

"Hai orang beriman, janganlah kamu saling memakan harta sesamamu dengan jalan yang bathil, kecuali dengan jalan perniagaan yang berlaku dengan suka sama suka di antara kamu...” (QS Al-Maa-idah (5):1).

"Rasulullah SAW melarang jual beli (yang mengandung) gharar" (H.r. Al Baihaqi dari Ibnu Umar).

"Tidak boleh menjual sesuatu hingga kamu memiliki” (H.R. Baihaqi dari Hukaim bin Hizam).

Karakteristik reksadana syariah memiliki dewan pengawas syariah. Dewan pengawas syariah ini bertugas mengawasi fungsi-fungsi yang dijalankan oleh reksadana syariah, yang meliputi pengecekan kehalalaan dan promosi. Dewan pengawas syariah juga memberikan nasehat dan pertimbangan pemanfaatan dana sosial serta edukasi.

Fatra (2014), menjelaskan bahwa di dalam reksadana syariah terdapat proses screening yang merupakan proses penyaringan sekuritas yang sesuai dengan syariat dan juga proses cleansing yaitu proses penghapusan sekuritas yang tidak sesuai syariat sehingga keuntungan yang dihasilkan sekuritas tersebut harus dikeluarkan dan diamalkan.

Pertumbuhan reksadana syariah cukup pesat, hal ini ditandai pertumbuhan Nilai Aktiva Bersih (NAB) pada tahun 2017 sebesar 38,25 persen. Lebih besar dibanding reksadana konvensional yang menunjukkan Nilai Aktiva Bersih (NAB) sebesar 25,45 persen. Nilai Aktiva Bersih (NAB) pada Desember 2016 tercatat hanya sebesar Rp 14,91 triliun meningkat menjadi Rp 20,62 triliun pada tahun 2017.

Perkembangan reksadana syariah yang pesat ini diikuti dengan jumlah produk reksadana syariah dari 136 produk (Desember 2016) menjadi 160 produk per Agustus. Jumlah produk reksadana konvensional per Agustus mencapai 1469 produk. Pangsa pasar reksadana syariah hanya 5 persen dibanding total reksadana secara nasional (www.ojk.com).

Kinerja reksadana syariah cukup bagus, hal ini ditunjukkan dengan imbal hasil reksadana saham syariah sebesar 1,44 persen. Kinerja reksadana yang meningkat hal ini disebabkan oleh infrastruktur dan komoditas yang naik. Reksadana diperkirakan akan memberikan imbal hasil yang meningkat. Reksadana syariah saham imbal hasilnya sebesar 10 persen, syariah campuran 8 persen, pendapatan syariah 7 persen, pasar uang syariah 4 persen. Kinerja ini ditompang oleh saham yang bergerak di sektor infrastruktur dan aneka industri (Hendrayana, 2017).

Kinerja reksadana yang selalu meningkat akan menarik bagi para investor. Investor banyak memilih reksadana syariah karena ingin memperoleh keberkahan tidak hanya keuntungan yang besar. Reksadana syariah juga memberikan imbal hasil yang jauh lebih tinggi dibanding reksadana 
konvensional. Oleh karena itu, dalam mengukur kinerja reksadana tidak hanya dilihat dari return yang akan didapatkan, melainkan juga harus memperhitungkan besar resiko yang akan diterima. Terdapat beberapa metode yang termasuk risk adjusted return, yaitu metode sharpe, metode teynor, metode jensen.

Metode sharpe mendasarkan perhitungan pada konsep garis pasar modal sebagai patok duga, yaitu dengan cara membagi premi resiko portofolio dengan standart deviasinya (resiko total), sehingga bisa mengukur premi resiko untuk setiap unit resiko pada portofolio tersebut (Tanderlilin, 2010). Kinerja portofolio dapat diukur hanya dengan satu metode, Metode Indeks Sharpe ini sudah mengakomodir kebutuhan calon investor karena telah memperhitungkan resiko secara keseluruhan (Rahma, 2016).

Metode Sharpe merupakan standart pengukuran kinerja reksadana secara Internasional yang dikembangkan oleh William F. Sharpe pada tahun 1966 yang telah teruji. Secara umum model pengukuran kinerja metode Sharpe dapat diterapkan untuk semua jenis reksadana sehingga pengguna metode ini dapat menggambarkan kemampuan manajer investasi dalam mengolah reksadana dari setiap unit resiko yang diambil. Selain itu, disebutkan dalam situs www.bareksa.com bahwa metode Sharpe ini merupakan salah satu metode yang paling banyak digunakan di Indonesia. Dalam ajang penghargaan reksadana terbaik 2013, penggunaan metode Sharpe salah satunya merupakan kriteria dalam menentukan reksadana terbaik tersebut (www.bareksa.com).

Penelitian ini didukung penelitian-penelitian terdahulu seperti Wiksuana (2008) dan Suryatini (2007) menyatakan kinerja reksadana syariah pendapatan tetap lebih baik dari kinerja pasarnya, begitu pula dengan penelitian Hakim \& Rashidian (2002), Haruman \& Hasbi (2005) bahwa reksadana syariah saham berkinerja lebih baik dari indeks pasarnya.

\section{METODE}

Penelitian ini merupakan penelitian studi kasus. Jenis penelitian yang dilakukan yaitu penelitian deskriptif kuantitatif. Subjek penelitian dalam penelitian ini adalah seluruh jenis reksadana syariah yang terdaftar di Bursa Efek Indonesia pada periode 2015-2017 setidaknya ada 10 jenis reksadana syariah, dan hanya ada 4 jenis reksadana syariah yang dianalisis dalam penelitian ini yaitu;

1. Reksadana Syariah Saham

2. Reksadana Syariah Pendapatan Tetap

3. Reksadana Syariah Campuran

4. Reksadana Syariah Pasar Uang

Pemilihan ke empat jenis reksadana syariah tersebut berdasarkan kriteria yang diambil sebagai berikut.

1) Sampel yang digunakan merupakan reksadana syariah yang aktif beroperasi di pasar modal Indonesia pada tahun 2015-2017.

2) Sampel yang digunakan merupakan reksadana syariah yang memiliki kinerja terbaik pada tahun 2015-2017 dilihat dari NAB (Nilai Aktiva Bersih).

Penelitian ini hanya menggunakan data sekunder. Metode pengumpulan data dalam penelitian ini adalah teknik dokumentasi. Teknik dokumentasi 
dilakukan dengan cara mendownload atau mengcopy data yang ada pada jasa keuangan, infovesta, bareksa dan badan pengawas pasar modal.

Analisis data dilakukan dengan tahapan sebagai berikut :

1) Tingkat Pengembalian Realisasi Reksadana

Menurut Jogiyanto (2009), Tingkat pengembalian dapat diukur dengan menggunakan rumus sebagai berikut.

Keterangan:

$$
R_{I}=\frac{N A B_{t}-N A B_{t-1}}{N A B_{t-1}}
$$

$\mathrm{Ri}=$ Tingkat pengembalian Investasi

NABt $=$ NAB bulan sekarang

NABt-1 = NAB bulan lalu

2) Menentukan Tingkat Pengembalian ekspektasi reksadana

Keterangan:

$$
E\left(R_{I}\right)=\frac{\sum_{t=1}^{n} R_{i}}{n-1}
$$

$\mathrm{E}(\mathrm{Ri}) \quad=$ Tingkat pengembalian ekspektasi reksadana $\mathrm{i}$

$\mathrm{Ri}=$ Tingkat pengembalian Realisasi dari reksadana $\mathrm{i}$

$\mathrm{n}=$ Jumlah periode selama transaksi

3) Menentukan Tingkat Risiko Reksadana

a. Menentukan variance reksadana

$$
\operatorname{Var}\left(R_{i}\right)=\frac{\sum_{I=1}^{n}\left(\left(R i-E\left(R_{I}\right)\right)^{2}\right.}{n-1}
$$

Keterangan:

$\operatorname{Var}(\mathrm{Ri}) \quad=$ Variance dari pengembalian investasi

$\mathrm{E}(\mathrm{Ri}) \quad=$ Tingkat pengembalian ekspektasi reksadana $\mathrm{i}$

Ri = Tingkat pengembalian Realisasi dari reksadana i

$\mathrm{n} \quad=$ Jumlah periode selama transaksi

b. Menentukan standar deviasi reksadana

$$
\sigma i=\sqrt{\operatorname{var}\left(E\left(R_{I}\right)\right.}
$$

Keterangan:

бi $\quad=$ Standar deviasi reksadana

$\operatorname{Var}(\mathrm{Ri}) \quad$ Variance dari pengembalian investasi

c. Menentukan covariance Reksadana

$$
\operatorname{COV}_{(A, B)}=\sum_{t=1}^{n}\left(P_{i}\right)\left(\left(R_{A I}-E\left(R_{i}\right)\right)\left(R_{B i}-E\left(R_{B}\right)\right)\right.
$$

Keterangan:

$\mathrm{Pi}=$ probabilitas diraihnya tingkat pengembalian

$\mathrm{RAi}=$ tingkat pengembalian realisasi dari investasi pada saham $\mathrm{A}$ pada keadaan i

$\mathrm{RBi} \quad=$ tingkat pengembalian realisasi dari investasi pada saham $\mathrm{B}$ pada keadaan i 
$\mathrm{E}(\mathrm{RA}) \quad=$ tingkat pengembalian ekspektasi dari investasi saham $\mathrm{A}$

$\mathrm{E}(\mathrm{RB}) \quad=$ tingkat pengembalian ekspektasi dari investasi saham $\mathrm{B}$

4) Mengukur Kinerja Reksadana Menggunakan Metode Sharpe

Keterangan:

$$
S p_{i}=\frac{R p_{i}-R_{f}}{S D p_{i}}
$$

$S p_{i} \quad=$ Indeks Sharpe portofolio i

$R p_{i} \quad=$ rerata imbal hasil portofolio i

$R_{f} \quad=$ rerata atas bunga investasi bebas risiko

$S D p_{i} \quad=$ standar deviasi dari imbal hasil portofolio i

\section{HASIL DAN PEMBAHASAN}

Penelitian ini dilakukan untuk mengetahui tingkat kinerja dari reksadana syariah pendapatan tetap, reksadana syariah saham, reksadana syariah pasar uang, serta reksadana syariah campuran yang diperdagangkan pada Pasar Modal Indonesia. Analisis kinerja reksadana syariah dalam penelitian ini, sesuai dengan metode analisis penelitian ini dengan menggunakan tingkat pengembalian, risiko, dan alat ukur kinerja berbasis risiko dilakukan dengan urutan reksadana syariah saham lebih dulu, lalu diikuti dengan reksadana syariah pendapatan tetap, reksadana syariah campuran, dan diakhiri dengan reksadana syariah pasar uang. Alat ukur kinerja berbasis risiko atas reksadana syariah saham, campuran, pendapatan tetap, dan pasar uang menggunakan indek Sharpe.

\section{Menentukan Tingkat Pengembalian}

Analisis kinerja reksadana syariah yang pertama yaitu menggunakan tingkat pengembalian bulanan, yang dicari dengan menentukan tingkat pengembalian tertinggi, terendah, dan rata-rata (ekspektasi) bulan Januari Desember pada 2015, 2016, dan 2017. Hasil perhitungan tingkat pengembalian bulanan reksadana syariah saham pada 2015, 2016, dan 2017 dapat dilihat pada Tabel 1.

Tabel 1. Hasil Tingkat Pengembalian Realisasi dan Ekspektasi

Reksadana Syariah Saham Bulanan Pada Tahun 2015-2017

\begin{tabular}{|l|l|l|l|}
\hline Tahun & \multicolumn{1}{|c|}{ Keterangan } & \multicolumn{1}{c|}{ Ri\% } & \multicolumn{1}{c|}{$\mathrm{E}(\mathrm{Ri})$} \\
\hline \multirow{3}{*}{2015} & Tertinggi (Oktober) & 11,3425 & 0,43625 \\
\cline { 2 - 4 } & Terendah (Agustus) & $-10,51$ & $-0,40423$ \\
\cline { 2 - 4 } & Rata-rata & $-1,38149$ & $-0,05313$ \\
\hline \multirow{2}{*}{2016} & Tertinggi (Juli) & 8,691667 & 0,334295 \\
\cline { 2 - 4 } & $\begin{array}{l}\text { Terendah } \\
\text { (November) }\end{array}$ & $-6,37333$ & $-0,24513$ \\
\cline { 2 - 4 } & Rata-rata & 1,453528 & 0,055905 \\
\hline \multirow{2}{*}{2017} & Tertinggi (Januari) & 3,790833 & 0,125801 \\
\cline { 2 - 4 } & $\begin{array}{l}\text { Terendah } \\
\text { (September) }\end{array}$ & $-2,72$ & $-0,10462$ \\
\cline { 2 - 4 } & Rata-rata & 0,496461 & 0,019095 \\
\hline
\end{tabular}

Sumber : data diolah (2018)

Berdasarkan tabel 1 diatas pada kolom Ri menunjukkan bahwa nilai tingkat pengembalian realisasi reksadana syariah saham paling tinggi pada tahun 
2015 yaitu pada bulan Oktober sebesar 11,3425. Nilai Ri terendah pada tahun yang sama bulan Agustus sebesar -10,51. Nilai Ri tertinggi selanjutnya ada pada tahun 2016 pada bulan Juli tercatat sebesar 8,691667, dan terendah kedua ada pada tahun 2016 juga di Bulan November sebesar -6,37333. Nilai Ri tertinggi ketiga ada di tahun selanjutnya yaitu 2017 sebesar 3,790833, dan Ri terendah ketiga ada di bulan September tahun 2017 sebesar -2,72.

Pada tahun 2015, menunjukkan bahwa tingkat pengembalian realisasi tertinggi dan terendah memiliki nilai yang lebih tinggi daripada tingkat pengembalian ekspetasi pada reksadana syariah saham. Pada tahun 2016 dan 2017 menunjukkan bahwa tingkat pengembalian realisasi lebih tinggi dari tingkat pengembalian ekspetasi hal ini menunjukkan kinerja yang terbaik reksadana saham syariah pada tahun 2016 meskipun tingkat pengembalian pada tahun 2015 lebih besar dibandingkan tahun 2016 tetapi dilihat dari nilai rata rata tingkat pengembalian masih lebih besar tahun 2016.

Analisis tingkat pengembalian kedua dilakukan pada reksadana syariah pendapatan tetap. Hasil perhitungan tingkat pengembalian bulanan tertinggi, terendah, dan rata-rata pada reksadana pendapatan tetap pada Januari Desember 2015, 2016, dan 2017 secara lengkap pada Tabel 2.

Tabel 2. Hasil Tingkat Pengembalian Realisasi dan Ekspektasi

Reksadana Syariah Pendapatan Tetap Bulanan pada 2015-2017

\begin{tabular}{|l|l|l|l|}
\hline Tahun & \multicolumn{1}{|c|}{ Keterangan } & \multicolumn{1}{c|}{ Ri\% } & \multicolumn{1}{c|}{$\mathrm{E}(\mathrm{Ri})$} \\
\hline \multirow{2}{*}{2015} & Tertinggi (Oktober) & 1,83 & 0,0703846 \\
\cline { 2 - 4 } & Terendah (Agustus) & $-0,055$ & $-0,0021154$ \\
\cline { 2 - 4 } & Rata-rata & 0,579167 & 0,0222756 \\
\hline \multirow{2}{*}{2016} & Tertinggi (Maret) & 1,665 & 0,064038 \\
\cline { 2 - 4 } & Terendah (Maret) & $-0,355$ & $-0,01365$ \\
\cline { 2 - 4 } & Rata-rata & 0,744583 & 0,028093 \\
\hline \multirow{2}{*}{2017} & $\begin{array}{l}\text { Tertinggi } \\
\text { (September) }\end{array}$ & 1,635 & 0,062885 \\
\cline { 2 - 4 } & $\begin{array}{l}\text { Terendah } \\
\text { (September) }\end{array}$ & $-0,075$ & $-0,00288$ \\
\cline { 2 - 4 } & Rata-rata & 0,566667 & 0,021795 \\
\hline
\end{tabular}

Sumber : data diolah (2018)

Berdasarkan tabel 2 diatas tingkat pengembalian terbesar yang diberikan kepada investor ada pada tahun 2015 bulan Januari yaitu sebesar 1,83. Nilai Ri selanjutnya ada di tahun 2016 bulan Maret yaitu tercatat sebesar 1,665. Pada tahun 2017 nilai Ri masih menunjukkan nilai positif, akan tetapi mengalami penurunan sebesar 0,03 menjadi 1,635. Nilai Ri terendah ada di tahun 2016 pada bulan November sebesar -0,355.

Kinerja reksadana syariah pendapatan tetap terbaik ada di tahun 2016 meskipun secara nilai tingkat pengembalian selalu mengalami penurunan akan tetapi rata - rata pada tahun 2016 lebih tinggi apabila dibanding lainnya, selain itu juga nilai pengembalian ekspetasi masih lebih kecil dibanding tingkat pengembalian realisasinya.

Analisis tingkat pengembalian ketiga dilakukan pada reksadana syariah campuran. Hasil perhitungan tingkat pengembalian bulanan tertinggi, terendah, dan rata-rata pada reksadana pendapatan tetap pada Januari - Desember 2015, 2016, dan 2017 secara lengkap pada Tabel 3. 
Tabel 3. Hasil Tingkat Pengembalian Realisasi dan Ekspektasi

Reksadana Syariah Campuran Bulanan pada 2015-2017

\begin{tabular}{|l|l|l|l|}
\hline Tahun & \multicolumn{1}{|c|}{ Keterangan } & \multicolumn{1}{c|}{ Ri\% } & \multicolumn{1}{c|}{$\mathrm{E}(\mathrm{Ri})$} \\
\hline \multirow{3}{*}{2015} & Tertinggi (Oktober) & 8,744286 & 0,336319 \\
\cline { 2 - 4 } & Terendah (Agustus) & $-7,06714$ & $-0,2718$ \\
\cline { 2 - 4 } & Rata-rata & $-0,56869$ & $-0,02187$ \\
\hline \multirow{2}{*}{2016} & Tertinggi (Juli) & 6,795714 & 0,261374 \\
\cline { 2 - 4 } & $\begin{array}{l}\text { Terendah } \\
\text { (November) }\end{array}$ & $-5,36286$ & $-0,20626$ \\
\cline { 2 - 4 } & Rata-rata & 1,158929 & 0,044574 \\
\hline \multirow{2}{*}{2017} & Tertinggi (Januari) & 2,687143 & 0,103352 \\
\cline { 2 - 4 } & $\begin{array}{l}\text { Terendah } \\
\text { (September) }\end{array}$ & $-0,96714$ & $-0,0372$ \\
\cline { 2 - 4 } & Rata-rata & 0,524524 & 0,020174 \\
\hline
\end{tabular}

Sumber : data diolah (2018)

Berdasarkan tabel 3 diatas pada kolom Ri menunjukkan bahwa nilai tingkat pengembalian terbesar yang di dapat investor yang menanamkan modalnya di reksadana syariah campuran ada di tahun 2015 pada bulan Oktober sebesar 8,744286. Nilai Ri selanjutnya ada di tahun 2016 bulan Juli sebesar 6,795714. Dari tiga tahun terhitung nilai tingkat pengembalian realisasi selalu mengalami penurunan.

Kinerja reksadana syariah campuran terbaik ada di tahun 2016 dimana nilai tingkat pengembalian realisasi sebesar 6,795714 lebih besar dibandingkan nilai tingkat pengembalian ekspetasi yang hanya sebesar 0,261374. Nilai tingkat rata-rata pengembalian realisasi pada tahun 2016 sebesar 1,158929 lebih besar dibandingkan tahun sebelum dan sesudahnya.

Analisis tingkat pengembalian terakhir, dilakukan pada reksadana syariah pasar uang. Hasil perhitungan tingkat pengembalian bulanan tertinggi, terendah, dan rata-rata pada reksadana pendapatan tetap pada Januari - Desember 2015, 2016, dan 2017 secara lengkap pada Tabel 4.

Berdasarkan tabel 4 diatas pada kolom Ri menunjukkan bahwa nilai tingkat pengembalian realisasi yang diberikan kepada investor terbesar pada tahun 2015 yaitu pada bulan September sebesar 0,645. Nilai Ri realisasi reksadana syariah pasar uang setiap tahunnya mengalami penurunan tingkat pengembalian disertai menurunnya nilai rata-rata pengembalian. Kinerja terbaik reksadana syariah pasar uang terbaik pada tahun 2015 dimana tingkat pengembalian terbesar dan nilai tingkat pengembalian ekspetasi lebih kecil dibandingkan tingkat pengembalian realisasinya.

Tabel 5. Tingkat Pengembalian Rata-Rata Tahunan Reksadana Syariah pada $2015-2017$

\begin{tabular}{|l|l|l|l|l|}
\hline Tahun & $\begin{array}{l}\text { ReksadanaSyariah } \\
\text { Saham }\end{array}$ & $\begin{array}{l}\text { ReksadanaSyariah } \\
\text { Pendapatantetap }\end{array}$ & $\begin{array}{l}\text { ReksadanaSyariah } \\
\text { Campuran }\end{array}$ & $\begin{array}{l}\text { Reksadana } \\
\text { Syariah } \\
\text { pasaruang }\end{array}$ \\
\hline 2015 & $-1,38149$ & 0,579167 & $-0,56869$ & 0,4895833 \\
\hline 2016 & 1,453528 & 0,744583 & 1,158929 & 0,472083 \\
\hline 2017 & 0,496461 & 0,566667 & 0,524524 & 0,4979167 \\
\hline
\end{tabular}

Sumber : data diolah 
Berdasarkan tabel 5 diatas menunjukkan kinerja berbagai jenis reksadana syariah seperti reksadana syariah saham, reksadana syariah pendapatan tetap, reksadana syariah campuran, reksadana syariah pasar uang. Pada tabel diatas jenis reksadana syariah yang memberikan kontribusi terbesar kepada investor yaitu reksadana syariah saham pada tahun 2016 sebesar 1,453528. Tingkat pengembalian rata-rata terbesar selanjutnya yaitu reksadana syariah campuran sebesar 1,158929. Tingkat pengembalian rata-rata ketiga yaitu reksadana syariah pendapatan tetap, dan reksadana yang menduduki peringkat paling akhir atau memiliki nilai rata-rata pengembalian realisasi paling kecil yaitu reksadana pasar uang. Kesimpulan dari pada tabel 5 yaitu reksadana yang memberikan tingkat pengembalian rata-rata tertinggi adalah reksadana saham.

\section{Pengukuran Risiko}

Alat analisis kinerja reksadana syariah kedua adalah risiko, yang diukur dengan deviasi standar atas tingkat pengembalian bulanan. Standar deviasi dihitung setiap bulan dengan hasil reksadana dengan risiko tertinggi, terendah, dan rata-rata pada 2015, 2016, dan 2017. Perhitungan standar deviasi dimulai dari reksadana syariah saham, setelahnya reksadana syariah pendapatan tetap, reksadana syariah campuran, dan reksadana syariah pasar uang.

Hasil perhitungan standar deviasi bulanan untuk reksadana syariah saham pada 2015, 2016, 2017, secara lengkap dapat dilihat pada tabel 6 . berdasarkan data pada tabel 6 pada kolom standar deviasi menunjukkan nilai risiko reksadana saham terbesar pada tahun 2015 bulan Oktober yaitu sebesar 55,61118, sedangkan paling rendah pada tahun 2017 bulan Febuari sebesar 2,9499135. Kesimpulan hasil perhitungan resiko reksadana saham bahwa resiko paling tinggi pada tahun 2015 dengan nilai rata-rata sebesar 21,34515. Resiko turun pada tahun 2016 sebesar 17,13257 dan hanya sebesar 9,2790993 pada tahun 2017. Resiko mengalami penurunan setiap tahunnya.

Tabel 6. Hasil Pengukuran Risiko (Standar Deviasi)

Reksadana Syariah Saham Bulanan pada 2015-2017

\begin{tabular}{|c|c|c|c|}
\hline Tahun & Bulan & Keterangan & Standar deviasi \\
\hline \multirow{3}{*}{2015} & \multirow[t]{3}{*}{$\begin{array}{l}\text { Januari } \\
\text { Desember }\end{array}$} & $\begin{array}{l}\text { Tertinggi } \\
\text { (Oktober) }\end{array}$ & 55,61118 \\
\hline & & Terendah (Mei) & 6,663863 \\
\hline & & Rata-Rata & 21,34515 \\
\hline \multirow[b]{3}{*}{2016} & \multirow{3}{*}{$\begin{array}{l}\text { Januari } \\
\text { Desember }\end{array}$} & Tertinggi (Juli) & 42,6144 \\
\hline & & Terendah (Mei) & 3,173813 \\
\hline & & Rata-Rata & 17,13257 \\
\hline \multirow{3}{*}{2017} & \multirow[t]{3}{*}{$\begin{array}{l}\text { Januari } \\
\text { Desember }\end{array}$} & Tertinggi (Januari) & 18,58609 \\
\hline & & $\begin{array}{l}\text { Terendah } \\
\text { (Febuari) }\end{array}$ & 2,9499135 \\
\hline & & Rata-Rata & 9,2790993 \\
\hline
\end{tabular}


Analisis perhitungan risiko, dengan standar deviasi, yang kedua adalah reksadana pendapatan tetap. Standar deviasi bulanan pada 2015, 2016, dan 2017 secara lengkap dapat dilihat pada Tabel 7. Berdasarkan data pada Tabel 7 pada kolom deviasi standar dapat dilihat bahwa risiko reksadana syariah pendapatan tetap terbesar terjadi pada tahun 2015 bulan Januari sebesar 8,972313, terendah bulan Mei 2015 sebesar 1,103153, rata-rata resiko bulan Januari-Desember tahun 2015 sebesar 3,342 146. Rata-rata tertinggi ada di tahun 2016 yaitu sebesar 3,984344. Kesimpulan dari hasil perhitungan resiko reksadana syariah pendapatan tetap bahwa resiko tertinggi ada pada tahun 2016.

Tabel 7. Hasil Pengukuran Risiko (Standar Deviasi)

Reksadana Syariah Pendapatan Tetap Bulanan pada 2015-2017

\begin{tabular}{|l|l|l|l|}
\hline Tahun & Bulan & Keterangan & $\begin{array}{l}\text { Standar } \\
\text { deviasi }\end{array}$ \\
\hline \multirow{2}{*}{2015} & $\begin{array}{l}\text { Januari sampai } \\
\text { Desember }\end{array}$ & Tertinggi (Januari) & 8,972313 \\
\cline { 3 - 4 } & & Terendah (Mei) & 1,103153 \\
\cline { 3 - 4 } & & Rata-Rata & 3,342146 \\
\hline \multirow{2}{*}{2016} & $\begin{array}{l}\text { Januari sampai } \\
\text { Desember }\end{array}$ & Tertinggi (Maret) & 8,163334 \\
\cline { 3 - 4 } & & $\begin{array}{l}\text { Terendah } \\
\text { (November) }\end{array}$ & 2,230821 \\
\cline { 3 - 4 } & & Rata-Rata & 3,984344 \\
\hline \multirow{2}{*}{2017} & \multirow{2}{*}{$\begin{array}{l}\text { Januari sampai } \\
\text { Desember }\end{array}$} & Tertinggi(September) & 8,016247 \\
\cline { 3 - 4 } & & Terendah (Desember) & 1,568929 \\
\cline { 3 - 4 } & & & 3,072486 \\
\cline { 3 - 4 } & & Rata-Rata & \\
\hline
\end{tabular}

Sumber : data diolah

Analisis perhitungan risiko, dengan standar deviasi yang ketiga adalah reksadana campuran. Standar deviasi bulanan pada 2015, 2016, dan 2017 secara lengkap dapat dilihat pada Tabel 8. Berdasarkan Tabel 8 pada kolom deviasi standar menunjukkan nilai risiko reksadana campuran terbesar pada tahun 2015 bulan Oktober sebesar 42,87239, terendah pada tahun 2017 bulan Mei sebesar 1,414838. Hasil Pengukuran Risiko rata-rata reksadana campuran terbesar pada tahun 2015 yaitu sebesar 15,00697. Rata- rata menurun pada tahun 2016 sebesar 13,74155. Resiko rata-rata reksadana syariah selalu mengalami penurunan setiap tahunnya pada tahun 2017 sebesar 6,137968. Kesimpulan dari hasil perhitungan resiko reksadana campuran bahwa resiko tertinggi ada di tahun 2015. 
Tabel 8. Hasil Pengukuran Risiko (Standar Deviasi)

Reksadana Syariah Campuran Bulanan pada 2015-2017

\begin{tabular}{|c|c|c|c|c|}
\hline Tahun & Bulan & & Keterangan & $\begin{array}{l}\text { Standar } \\
\text { deviasi }\end{array}$ \\
\hline \multirow[t]{3}{*}{2015} & \multirow[t]{3}{*}{$\begin{array}{l}\text { Januari } \\
\text { Desember }\end{array}$} & \multirow[t]{3}{*}{ sampai } & $\begin{array}{l}\text { Tertinggi } \\
\text { (Oktober) }\end{array}$ & 42,87239 \\
\hline & & & $\begin{array}{l}\text { Terendah } \\
\text { (Desember) }\end{array}$ & 3,803252 \\
\hline & & & Rata-Rata & 15,00697 \\
\hline \multirow{3}{*}{2016} & \multirow[t]{3}{*}{$\begin{array}{l}\text { Januari } \\
\text { Desember }\end{array}$} & \multirow[t]{3}{*}{ sampai } & $\begin{array}{l}\text { Tertinggi } \\
\text { (Juli) }\end{array}$ & 33,31873 \\
\hline & & & $\begin{array}{l}\text { Terendah } \\
\text { (Mei) }\end{array}$ & 4,041393 \\
\hline & & & Rata-Rata & 13,74155 \\
\hline \multirow{3}{*}{2017} & \multirow[t]{3}{*}{$\begin{array}{l}\text { Januari } \\
\text { Desember }\end{array}$} & \multirow[t]{3}{*}{ sampai } & $\begin{array}{l}\text { Tertinggi } \\
\text { (Januari) }\end{array}$ & 13,1748 \\
\hline & & & $\begin{array}{l}\text { Terendah } \\
(\mathrm{Mei})\end{array}$ & 1,414838 \\
\hline & & & Rata-Rata & 6,137968 \\
\hline
\end{tabular}

Sumber : data diolah

Analisis perhitungan risiko, dengan standar deviasi yang keempat adalah reksadana syariah pasar uang. Standar deviasi bulanan pada 2015, 2016, dan 2017 secara lengkap dapat dilihat pada Tabel 9. Berdasarkan tabel 9 pada kolom standar deviasi menunjukkan nilai risiko reksadana pasar uang terbesar pada 2017 yaitu bulan Juli sebesar 2,696597, terkecil pada 2015 Januari sebesar 0,001833303. Rata- rata tertinggi ada pada tahun 2017 yaitu sebesar 2,441237, yang menunjukkan resiko terbesar reksadana syariah pasar uang ada di 2017 sebesar 2,441237.

Tabel 9. Hasil Pengukuran Risiko (Standar Deviasi)

Reksadana Syariah Pasar Uang Bulanan pada 2015-2017

\begin{tabular}{|c|c|c|c|}
\hline Tahun & Bulan & Keterangan & $\begin{array}{l}\text { Standar } \\
\text { deviasi }\end{array}$ \\
\hline \multirow{3}{*}{2015} & \multirow[t]{3}{*}{$\begin{array}{l}\text { Januari } \\
\text { Desember }\end{array}$} & $\begin{array}{l}\text { Tertinggi } \\
\text { (April) }\end{array}$ & 0,132001245 \\
\hline & & $\begin{array}{l}\text { Terendah } \\
\text { (Januari) }\end{array}$ & 0,001833303 \\
\hline & & Rata-Rata & 0,092475074 \\
\hline \multirow{3}{*}{2016} & \multirow[t]{3}{*}{$\begin{array}{ll}\text { Januari } & \text { sampai } \\
\text { Desember } & \end{array}$} & $\begin{array}{l}\text { Tertinggi } \\
\text { (Januari) }\end{array}$ & 0,12257258 \\
\hline & & $\begin{array}{l}\text { Terendah } \\
\text { (Agustus, } \\
\text { September) }\end{array}$ & 0,02451452 \\
\hline & & Rata-Rata & 0,08902227 \\
\hline
\end{tabular}




\begin{tabular}{|c|c|c|c|c|}
\hline \multirow{3}{*}{2017} & \multirow{3}{*}{\multicolumn{2}{|c|}{$\begin{array}{l}\text { Januari } \\
\text { Desember }\end{array}$}} & $\begin{array}{l}\text { Tertinggi } \\
\text { (Juli) }\end{array}$ & 2,696597 \\
\hline & & & $\begin{array}{l}\text { Terendah } \\
\text { (November) }\end{array}$ & 2,230821 \\
\hline & & & Rata-Rata & 2,441237 \\
\hline
\end{tabular}

Sumber : data diolah

Tabel.10 Risiko Rata-rata BulananReksadana Syariahpada 2015 - 2017

\begin{tabular}{|l|l|l|l|l|}
\hline Tahun & $\begin{array}{l}\text { ReksadanaSyari } \\
\text { ah Saham }\end{array}$ & $\begin{array}{l}\text { ReksadanaSyari } \\
\text { ah } \\
\text { Pendapatantetap }\end{array}$ & $\begin{array}{l}\text { ReksadanaSyari } \\
\text { ah Campuran }\end{array}$ & $\begin{array}{l}\text { Reksadana } \\
\text { Syariah } \\
\text { pasaruang }\end{array}$ \\
\hline 2015 & 21,34515 & 3,342146 & 15,00697 & $\begin{array}{l}0,0924750 \\
74\end{array}$ \\
\hline 2016 & 17,13257 & 3,984344 & 13,74155 & $\begin{array}{l}0,0890222 \\
7\end{array}$ \\
\hline 2017 & 9,2790993 & 3,072486 & 6,137968 & 2,441237 \\
\hline
\end{tabular}

Sumber : data diolah

Berdasarkan Tabel 10 menunjukkan risiko rata-rata berbagai jenis reksadana syariah yang memberikan kontribusi terbesar kepada investor yaitu reksadana syariah saham sebesar 21,34515 persen pada 2015. Risiko rata-rata terbesar selanjutnya yaitu reksadana syariah Campuran sebesar 15,00697 pada tahun 2015. Risiko rata-rata berikutnya yaitu reksadana syariah pendapatan tetap tahun 2016 yaitu 3,984344. Risiko terkecil ada di reksadana pasar uang pada tahun 2017 sebesar 2,441237. Kesimpulan dari pada tabel 10 yaitu reksadana syariah yang memberikan risiko rata-rata tertinggi adalah reksadana syariah saham.

3. Pengukuran Kinerja Reksadana Menggunakan Metode Sharpe

Pengukuran kinerja reksadana pertama, adalah kinerja semua jenis reksadana pada 2015, yaitu reksadana syariah saham, reksadana syariah pendapatan tetap, reksadana syariah campuran, dan reksadana syariah pasar uang. Hasil perhitungan Indeks Sharpe dari semua jenis reksadana syariah tersebut dapat dilihat pada Tabel 11. Berdasarkan tabel 11 menunjukkan bahwa kinerja reksadana syariah terbaik pada tahun 2015 adalah reksadana syariah saham yang mempunyai nilai indeks Sharpe sebesar 0,069096. Kinerja reksadana syariah terbaik kedua adalah reksadana syariah campuran dengan nilai Sharpe 0,029023. Kinerja selanjutnya yaitu reksadana syariah pendapatan tetap sebesar 0,659808 dan terakhir reksadana syariah pasar uang sebesar $-51,5147$.

Tabel 11. Hasil Indeks Sharpe Reksadana Syariah Pada Tahun 2015

\begin{tabular}{|c|l|c|c|c|c|}
\hline Tahun & Bulan & Saham & Campuran & $\begin{array}{c}\text { Pendapatan } \\
\text { Tetap }\end{array}$ & Pasar uang \\
\hline \multirow{7}{*}{} & Januari & $-0,6456$ & $-0,46502$ & $-0,659808$ & $-4227,34$ \\
\cline { 2 - 6 } & Febuari & $-0,42793$ & $-0,44071$ & $-2,013004$ & $-63,27$ \\
\cline { 2 - 6 } & Maret & $-0,50557$ & $-0,62142$ & $-5,568514$ & $-54,9582$ \\
\cline { 2 - 6 } & April & $-1,29742$ & $-1,90207$ & $-2,637177$ & $-51,5147$ \\
\cline { 2 - 6 } & Mei & $-0,83358$ & $-1,77384$ & $-6,84855$ & $-131,843$ \\
\cline { 2 - 6 } & Juni & $-0,39468$ & $-0,48115$ & $-4,895059$ & $-63,27$ \\
\cline { 2 - 6 } & Juli & $-0,72028$ & $-1,95936$ & $-1,281191$ & $-62,1078$ \\
\hline
\end{tabular}




\begin{tabular}{|l|l|c|c|c|c|}
\hline & Agustus & $-0,34951$ & $-0,42041$ & $-3,849437$ & $-61,5413$ \\
\cline { 2 - 6 } & September & $-0,92161$ & $-1,401$ & $-4,32456$ & $-56,3596$ \\
\cline { 2 - 6 } & Oktober & 0,069096 & 0,029023 & $-1,34904$ & $-63,27$ \\
\cline { 2 - 6 } & November & $-0,60722$ & $-0,78909$ & $-1,595693$ & $-300,638$ \\
\cline { 2 - 6 } & Desember & $-1,16737$ & $-2,14516$ & $-1,997055$ & $-70,4539$ \\
\hline
\end{tabular}

Sumber : data diolah

Analisis kinerja reksadana yang kedua, dengan Indeks Sharpe untuk semua jenis reksadana, hasilnya dapat dilihat pada Tabel 12. Berdasarkan Tabel 12 menunjukkan bahwa kinerja reksadana syariah terbaik pada 2016 adalah reksadana syariah saham yang mempunyai nilai indeks Sharpe sebesar 0,05143. Kinerja reksadana syariah terbaik kedua adalah reksadana campuran dengan nilai Sharpe 0,008875. Kinerja selanjutnya yaitu reksadana syariah pendapatan tetap sebesar -0,62291 dan terakhir reksadana syariah pasar uang sebesar $-53,8456$.

Tabel 4.12. Hasil Indeks Sharpe Reksadana Syariah Pada Tahun 2016

\begin{tabular}{|c|l|c|c|c|c|}
\hline Tahun & Bulan & Saham & Campuran & $\begin{array}{c}\text { Pendapatan } \\
\text { Tetap }\end{array}$ & Pasar uang \\
\hline \multirow{7}{*}{2016} & Januari & $-0,85072$ & $-0,68074$ & $-1,34443$ & $-53,8456$ \\
\cline { 2 - 6 } & Febuari & $-0,0632$ & $-0,16293$ & $-1,11192$ & $-58,6985$ \\
\cline { 2 - 6 } & Maret & $-0,03171$ & $-0,1203$ & $-0,62291$ & $-61,6038$ \\
\cline { 2 - 6 } & April & $-0,53828$ & $-1,15982$ & $-1,41573$ & $-54,8569$ \\
\cline { 2 - 6 } & Mei & $-2,18853$ & $-1,63239$ & $-2,78028$ & $-60,3761$ \\
\cline { 2 - 6 } & Juni & $-0,3628$ & $-0,42435$ & $-1,96939$ & $-64,3321$ \\
\cline { 2 - 6 } & Juli & 0,05143 & 0,008875 & $-1,00677$ & $-67,2641$ \\
\cline { 2 - 6 } & Agustus & $-0,17285$ & $-0,18111$ & $-1,82008$ & $-259,846$ \\
\cline { 2 - 6 } & September & $-0,88524$ & $-1,15747$ & $-1,78964$ & $-259,846$ \\
\cline { 2 - 6 } & Oktober & $-1,11373$ & $-1,53169$ & $-2,42128$ & $-65,0427$ \\
\cline { 2 - 6 } & November & $-0,41198$ & $-0,45117$ & $-3,07286$ & $-62,9532$ \\
\cline { 2 - 6 } & Desember & $-0,69286$ & $-0,89394$ & $-1,5637$ & $-59,1258$ \\
\hline
\end{tabular}

Sumber : data diolah

Analisis kinerja reksadana syariah yang ketiga, dengan Indeks Sharpe untuk semua jenis reksadana, hasilnya dapat dilihat pada Tabel 4.13. Berdasarkan Tabel 4.13 menunjukkan bahwa kinerja reksadana syariah terbaik pada 2017 adalah reksadana syariah saham yang mempunyai nilai indeks Sharpe sebesar -0,05161. Kinerja reksadana syariah terbaik kedua adalah reksadana campuran dengan nilai Sharpe -0,15658. Kinerja selanjutnya yaitu reksadana syariah pendapatan tetap sebesar -0,32621 dan terakhir reksadana syariah pasar uang sebesar $-1,44715$.

Tabel 13. Hasil Indeks Sharpe Reksadana Syariah Pada Tahun 2017

\begin{tabular}{|c|l|c|c|c|c|}
\hline Tahun & Bulan & Saham & Campuran & $\begin{array}{c}\text { Pendapatan } \\
\text { Tetap }\end{array}$ & Pasar uang \\
\hline \multirow{7}{*}{} & Januari & $-0,05161$ & $-0,15658$ & $-0,9563$ & $-1,60691$ \\
\cline { 2 - 6 } & Febuari & $-1,56728$ & $-1,36225$ & $-1,87951$ & $-1,65914$ \\
\cline { 2 - 6 } & Maret & $-0,58927$ & $-0,60119$ & $-1,87951$ & $-1,8144$ \\
\cline { 2 - 6 } & April & $-0,08873$ & $-0,27195$ & $-1,6414$ & $-1,75324$ \\
\cline { 2 - 6 } & Mei & $-0,71152$ & $-3,56124$ & $-2,37954$ & $-1,87951$ \\
\cline { 2 - 6 } & Juni & $-0,90655$ & $-0,66549$ & $-2,21807$ & $-1,75324$ \\
\cline { 2 - 6 } & Juli & $-0,67788$ & $-1,15453$ & $-1,29808$ & $-1,55752$ \\
\cline { 2 - 6 } & Agustus & $-0,56228$ & $-0,9159$ & $-1,95562$ & $-1,54427$ \\
\cline { 2 - 6 } & September & $-0,52265$ & $-0,77966$ & $-0,32621$ & $-1,44715$ \\
\hline
\end{tabular}




\begin{tabular}{|l|l|l|l|l|l|}
\hline & Oktober & $-0,27699$ & $-0,39301$ & $-1,36764$ & $-1,68046$ \\
\cline { 2 - 6 } & November & $-0,45138$ & $-1,21755$ & $-0,90029$ & $-1,70117$ \\
\cline { 2 - 6 } & Desember & $-0,65405$ & $-0,72419$ & $-2,50489$ & $-1,64037$ \\
\hline
\end{tabular}

Sumber : data diolah

Tabel.14 Kinerja Disesuaikan Risiko Reksadana Syariah pada 2015 - 2017

\begin{tabular}{|l|l|l|l|l|}
\hline Tahun & $\begin{array}{c}\text { Reksadana } \\
\text { Syariah } \\
\text { Saham }\end{array}$ & $\begin{array}{c}\text { Reksadana } \\
\text { Pendapatan } \\
\text { Tetap }\end{array}$ & $\begin{array}{c}\text { Reksadana } \\
\text { Campuran }\end{array}$ & $\begin{array}{c}\text { Reksadana } \\
\text { Pasar Uang }\end{array}$ \\
\hline 2015 & $-0,65014$ & $-3,084924$ & $-1,03085$ & $-433,881$ \\
\hline 2016 & $-0,60504$ & $-1,74325$ & $-0,62321$ & $-93,9826$ \\
\hline 2017 & $-0,58835$ & $-1,60892$ & $-0,98363$ & $-1,66978$ \\
\hline
\end{tabular}

Sumber : data diolah

Berdasarkan Tabel 14 menunjukkan kinerja berbagai jenis reksadana syariah yang terbaik yaitu reksadana syariah saham dengan nilai indeks Sharpe sebesar -0,58835 persen pada 2017. Kinerja terbaik selanjutnya yaitu reksadana syariah Campuran pada 2016 yaitu nilai Sharpe sebesar -0,62321 persen. Ketiga ada reksadana syariah pendapatan tetap nilai Sharpe sebesar $-1,60892$ persen pada tahun 2017 dan terakhir adalah reksadana syariah pasar uang nilai Sharpe sebesar -1,66978 persen. Kesimpulan dari pada tabel 14 yaitu kinerja reksadana syariah yang terbaik adalah reksadana syariah saham.

\section{SIMPULAN}

Hasil analisis data menunjukkan bahwa kinerja reksadana syariah yang terbaik adalah reksadana syariah saham. Reksadana syariah saham terbaik berdasarkan pengukuran kinerja dengan menggunakan metode sharpe dimana ada tiga indikator pengukuran kinerja, yaitu tingkat pengembalian yang dihitung secara bulanan dan rata-rata tahunan menunjukkan saham memperoleh hasil tertinggi dibandingkan ketiga jenis reksadana syariah lainnya. Kedua, tingkat resiko yang dihitung menggunakan standar deviasi. Reksadana syariah saham juga memiliki resiko yang tertinggi dibandingkan reksadana syariah lainnya secara bulanan dan rata-rata tahunan. Ketiga, indeks sharpe dimana nilai reksadana syariah saham lebih tinggi dibandingkan jenis reksadana syariah lainnya. Indeks sharpe yang semakin tinggi menunjukkan kinerja yang semakin baik.

\section{DAFTAR PUSTAKA}

Achsien, Inggi H. 2000. Investasi Syariah di Pasar Modal. Edisi 1. Jakarta: Gramedia Pustaka Utama.

Dewan Syariah Nasional,. 2003. Himpunan Fatwa Dewan Syariah Nasional. Bank Indonesia- Dewan Syariah Nasional. Edisi 2. Jakarta.

Fatra,O.S. 2014. Analisis Perbandingan Kinerja Reksadana Konvensional dengan Reksadana Syariah di Indonesia. Skripsi, Jember: FE UNEJ.

Hakim, S. \& Rashidian, M. 2002. Risk and Return of Islamic Stock Market. Presentation to Economic Research Forum Annual Meetings Shariah. UEA.

Halim (2015). Analisis Investasi dan Aplikasinya Dalam Aset Keuangan dan Aset Riil. Salemba. Jakarta Selatan. 
Haruman, T. \& Hasbi, H. 2005. Evaluasi Kinerja dan Prospek Feksadana Syariah dalam Pasar Modal di Indonesia. Usahawan, Vol. XXXIV No.01 (Januari 2005), 40-49.

Hasbi, H. 2010. Kinerja Reksadana Syariah Tahun 2009 di Indonesia. Vol.14 No.01 (Januari 2010), 62-73.

Hussein, K. \& Omran, M.2005. Ethical Investment Revisited: Evidence from Dow Jones Islamic Indices. The Journal of Investing, Vol.14, 105-124.

Indriantoro, Nur \& Bambang Supomo. 2016. Metodelogi Penelitian Bisnis untuk Akuntasi dan Manajemen. Edisi Ke-1. Yogyakarta: BPFE.

Jogianto (2009). Analisis Investasi dan Portofoli. BPFE. Yogyakarta.

Mediawati \& Waridah. 2016. Analisis Kinerja Reksadana Syariah. Vol.4 No.12, 142-153.

Natalia, S. 2015. Analisa Manajemen Portofolio Investasi Reksadana Syariah Ditinjau Dari Strategi Investasi Berdasarkan Resiko Investasi dan Pengukuran Kinerja. Vol.13 No.2 (Juli 2015), 187-199.

Pranoto, A. 2012. Analisis Kinerja Reksadana Syariah Dibandingkan Dengan Reksadana Konvensional di Indonesia. Skripsi. Universitas Indonesia. Jakarta.

Rofiq (2015). “Analisis kinerja reksadana dengan menggunakan metode Sharpe”, Jurnal Ilmu dan Manajemen. Vol.4, No. 7.

Soemitra, Andri. 2004. Masa Depan Pasar Modal Syariah. Edisi 1. Jakarta: Prenadamedia Grup.

Suryantini, N. P. S. 2007. Perbedaan Kinerja Portofolio berdasarkan Strategi Portofolio Aktif dan Pasif pada Saham LQ 45 di BEI. Buletin Studi Ekonomi, Vol.12 No 3, 299-313.

Sutedi, Andrian. 2011. Pasar Modal Syariah. Edisi 1. Jakarta: Sinar Grafika.

Tanderlilin, Eduardus. 2010. Portofolio dan Investasi. Yogyakarta: Kanisius.

Ulum, I., A. Juanda. 2016. Metodologi Penelitian Akuntansi. Edisi 2. Malang: Aditya Media Publishing.

Wiksuana, I.GB. \& Purnawati, N.K.2008, Konsistensi Risk-Adjusted Performance sebagai Pengukur Kinerja Portofolio Saham di Pasar Modal Indonesia. Buletin Studi Ekonomi, Vol.13 No.2, 174-183.

www.bareksa.com

www.bi.go.id

www.ojk.go.id 